\title{
STUDY THE NUTRITIONAL AND THERAPEUTIC EFFECT OF FLAXSEED, SUNFLOWER AND PUMPKIN SEEDS ON THE LEVEL OF BLOOD LIPIDS AND WEIGHT GAIN ON RATS
}

\author{
M. M. El Sayed and Fatma G. R. El Hawary \\ Nutrition and Food Science, Faculty of Home Economics, Minoufia University \\ Received: Mar. 24,2019 \\ Accepted: Jan. 23, 2019
}

\begin{abstract}
This study was conducted to investigate the use of flaxseed, sunflower and pumpkin seeds to improve the level of serum lipid profile, high liver enzymes, renal function and antioxidant enzymes. Fifty four mature male albino rats weighing $150+10 \mathrm{~g}$ were divided into two main groups; control negative group (6 rats) was fed on basal diet and the second main group (48 rats) which was fed on hyperlipidemic diet for four weeks to induce hyperlipidemia. Rats on the second main group supplements were divided into eight subgroups (each group consisted of 6 rats and fed on basal diet. Group were as a following: The first group was left as a control positive, the second group fed diet containing $5 \%$ flaxseeds / $\mathrm{kg}$ in diet. The third group fed diet containing $5 \%$ sunflower seeds / $\mathrm{kg}$ in diet. The fourth group fed diet containing $5 \%$ pumpkin seeds $\mathrm{kg}$ in diet. The fifth group fed diet containing $5 \%$ mix of pumpkin and sunflower seeds. The sixth group fed diet containing $5 \%$ mix of pumpkin and flaxseeds. The seventh group fed diet containing $5 \%$ mix of sunflower and flaxseeds. The eighth group fed diet containing $5 \%$ mix of sunflower, flaxseeds and pumpkin. Feeding experiment lasted for 28 days. Serum total cholesterol, triglycerides, lipoprotein fractions (HDLc, LDLC and VLDLC), atherogenic index (AI), liver enzymes( $A L T, A S T, A L P)$,total protein, albumin, globulin, albumin/globulin (A/G) ratio, uric acid, urea, creatinine, antioxidant levels superoxide dismutase (SOD), catalase (CAT), glutathione peroxidase (GPX) and malondialdehyde (MDA) were determined. Histopathological changes of heart was examined. The obtained results concluded that feeding with flaxseed (5\%), sunflower (5\%) and pumpkin seeds (5\%) improved liver, kidney functions, lipid profile, antioxidant levels (SOD), (CAT), (GPX), (MDA), heart tissues changes. According to the results, flaxseed, sunflower and pumpkin seeds could be used to improve the health situation of obese rats along with weight loss.
\end{abstract}

Key words: Obesity, flaxseed, sunflower, pumpkin, lipid profile, liver enzymes, antioxidant levels superoxide dismutase (SOD), catalase (CAT), glutathione peroxidase (GPX), malondialdehyde (MDA), histopathological changes.

\section{INTRODUCTION}

Obesity is a medical condition in which excess body fat has accumulated to an extent that it may have a negative effect on health (WHO,2016).People are generally considered obese when their body mass index (BMI), a measurement obtained by dividing a person's weight by the square of the person's height, is over $30 \mathrm{~kg} / \mathrm{m} 2$; the range $25-30 \mathrm{~kg} / \mathrm{m} 2$ is defined as overweight (Haslam and James, 2005).

Obesity increases the likelihood
of various diseases and conditions,
particularly cardiovascular diseases,
type 2 diabetes, obstructive sleep apnea,
certain types of cancer, osteoarthritis,
and depression (Luppino et al., 2010).
Obesity is most commonly caused by a


combination of excessive food intake, lack of physical activity, and genetic susceptibility (Yazdi et al., 2015).

A few cases are caused primarily by genes, endocrine disorders, medications, or mental disorder (Bleich et al., 2008). On average, obese people have a greater energy expenditure than their normal counterparts due to the energy required to maintain an increased body mass (Kushner, 2009). Obesity is mostly preventable through a combination of social changes and personal choices. Changes to diet and exercising are the main treatments (Yanovski and Yanovski, 2014).

Diet quality can be improved by reducing the consumption of energydense foods, such as those high in fat or sugars, and by increasing of fruit vegtables foods. Medications can be used, along with a suitable diet, to reduce appetite or decrease fat absorption (Colquitt et al., 2014). If diet, exercise, and medication are not effective, a gastric balloon or surgery may be performed to reduce stomach volume or length of the intestines, leading to feeling full earlier or a reduced ability to absorb nutrients from food (Imaz et al., 2008).

Flaxseeds help to reduce belly fat by increasing thermogenesis (a process by which fat is burnt). It perfectly balances the hormones which contribute to weight loss. The fiber in flaxseed promotes healthy bowel function. Hence, maintaining the colon health with prevention of constipation and further complications (Garg et al., 2017).

Sunflower seeds appear to be a perfect melting pot of nutrients that are conducive for weight loss, including those such as fiber and the $B$ vitamins. Fiber adds bulk in the stomach, slowing down glucose absorption and keeping you fill for longer, while the B vitamins help to ensure macronutrients are broken down in more efficient fashion. Both of these help in the weight loss process, and can help keep energy levels high while calories are restricted (Marcene, 2018).

Pumpkin seeds are full of fiber, which discourage more eating because of giving the feeling of full stomach. One cup of its seeds has about 600 calories, thus it fulfills your calorie intake to a greater extent of your body. Not only this, it also boosts your fiber intake. Therefore, the regular use of such seeds helps to control as well as management of weight (Megan, 2018).

Thereupon, this experiment was conducted to study the effect flaxseed, sunflower and pumpkin seeds on hyperlipidemic rats.

\section{MATERIALS AND METHODS}

\section{1- Food material:}

Flaxseed, sunflower and pumpkin seeds were obtained from Minstry of Agricultur. Basal diets were supplemented with flaxseed, sunflower and pumpkin seeds at concentration $5 \%$ for 28 days.

\section{2- Hyperlipidemic diet}

Hyperlipidemic diet was prepared from fine ingredients per $100 \mathrm{~g}$ according to Rashwan (1994). The diet had the following composition fat $\mathbf{2 0 \% ( s u n f l o w e r}$ oil10\% + sheep tallow $10 \%)$, sugar $10 \%$, salt mixture $4 \%$ vitamin mixture $1 \%$, casein (protein content 14\%), mithionine $0.3 \%$, and corn starch up to 100 .

\section{3- Chemicals:}

Casein, vitamins mixture, salt mixture and all other basal ingredients diet were purchased from El-Gomhoria Company, Cairo, Egypt. 
4- Experiments animals:

Fifty four male albino rats, weighing $150 \pm 10 \mathrm{~g}$, of Sprague Dawley Strain were used. They were obtained from the Animal House Laboratory of Ophthalmic Research Institute, Giza.

\section{Methods:}

\section{Biological experiments:}

Diet: The basal diet (casein - basal diet) was composed of $12.3 \mathrm{~g}$ casein $(\mathbf{8 0} \%$ protein), $10 \mathrm{~g}$ corn oil ( $10 \%$ fat $), 4 \mathrm{~g}$ cellulose ( $4 \%$ fiber), mineral mixture $(4 \%)$. vitamin in mixture (1\%) and corn starch up to $100 \mathrm{~g}$ according to NRC (1995). The salt mixture used in the experiment was composed according to Hegsted (1941). vitamin mixture used in the experiment was that of Campbell (1963) .

\section{Experimental design and animal groups:}

After one week of adiption, the rats were divided into two main groups as follows:-

- The first main group ( 6 rats) was fed on basal diet and kept as a control negative .

- The second main group (48 rats) was fed on hyperlipidemic diet for four weeks to induce hyperlipidemia and increased negative weight according to Rashwan (1994).

Rats in the second main group (48 rats ) were divided into eight groups (each group consisted of 6 rats). Grouping of all rats was as followings:

- The first group was left as a control positive and fed on hyperlipidemic diet. The second group was fed on basal diet and supplemented standard diets with $5 \%$ Flaxseeds. The third group was fed on basal diet and supplemented standard diets with $5 \%$ sunflower seeds. The fourth group was fed on basal diet and supplemented standard diets with $\mathbf{5 \%}$ pumpkin seeds. The fifth group was fed on basal diet and supplemented standard diets with $5 \%$ mix of pumpkin and sunflower seeds. The sixth group was fed on basal diet and supplemented standard diets with $5 \%$ mix of pumpkin seeds and flaxseeds. The seventh group was fed on basal diet and supplemented standard diets with $\mathbf{5 \%}$ mix of sunflower and flaxseeds. The eighth group was fed on basal diet and supplemented standard diets with $5 \%$ mix of flaxseeds, sunflower and pumpkin seeds.

During the experiment period (28 days), the quantities of diet consumed and $I$ or wasted were recorded every day. In addition, rats weight was recorded weekly.

At the end of the experiment period, the rats were fasted overnight before sacrificing and the blood samples were collected from each rat and centrifuged to obtain the serum. Serum was carefully separated and transferred into dry clean Ebendorf tubes and kept frozen at- $20^{\circ} \mathrm{C}$ till analysis as described by Schermer (1967).

Liver, heart and kidneys were removed from each rat by careful dissection, cleaned from the adhesive matter by a saline solution, wiped by filter paper, weighed and kept in formalin solution $(10 \%)$, according to the method described by (Drury and Walling, 1980).

\section{Biochemical analysis of serum:-}

1- Total cholesterol was determined according to Allain et al., (1974).

2- Triglycerides was determined according to Trinder and Ann (1969).

3- HDL-C was determined according to Lopes - Virella et al., (1977).

4- Serum VLDL-C was determined according to Friedwald et al., (1972) using the following equation: 
VLDL-C Concentration $(\mathrm{mg} / \mathrm{dl})=\underline{\mathrm{TG}(\mathrm{mg} / \mathrm{dl})}$

5- Serum LDL-C was determined according to Friedwald et al., (1972) using the following equation:

LDL-C = Total Cholesterol - [ (VLDL-C ) + ( HDL-C) ]

6- Serum LDL IHDL cholesterol, CRR cholesterol, AC cholesterol, AIP cholesterol and Atherogenic index was determined according to Bhardwaj et al., (2013) using the following equation:

Atherogenic Index $(\mathrm{Al})=\quad$ (VLDL+ LDL)/HDL cholesterol

LDL /HDL cholesterol= LDL-C / HDL-C

CRR cholesterol= TC/HDL-C

AC cholesterol=(TC- HDLC)/HDL-C

AIP cholesterol= log (TG/HDL-C)

Determination of liver functions:

1- AST (GOT) was determined according to Reitman and Frankel (1957).

2- ALT (GPT) was determined according to Reitman and Frankel (1957).

Determination of kidney functions:

1- Total protein was determined according to Sonnenwirth and Jaret (1980).

2- Albumin was determined by Drupt (1974).

3- Globulin was calculated from formula: Globulin= Total protein - Albumin.

4- A/G ratio was calculated from formula according to Catherine et al., (2003): A/G ratio =Albumin/ Globulin.

5- Urea nitrogen was determined by Patton and Crouch (1977).

6- Createnine was determined by Faulkner and King (1976).

7- Uric acid was determined by Barham and Trinder (1972) and Fossati et al., (1980).

Determination of serum
antioxidant status:-
1- superoxide dismutase (SOD) was
determined by Fossati et al., (1980).

2- catalase (CAT) was determined by Aebi (1984).

3- Glutathione peroxidase (GPX) was determined by Beutler et al., (1963).

4- Malondialdehyde (MDA) was determined by Ohkawa et al., (1979).

Statistical analysis: Data were expressed as (Mean \pm SD). Differences between control and treated groups were tested for significance using a one way analysis of variance (ANOVA test) according to Armitage and Berry (1987) followed by Duncan's range multiple test. Differences were considered of significance at a level of $P \leq 0.05$ using SPSS (version 20.0) computerized program.

\section{Histopathological examination of hearts :}

The hearts, of sacrificed rats were taken and immersed in $10 \%$ formalin solution. The fixed specimens were then trimmed, washed and dehydrated in ascending grades of alcohol. They were then cleared in xylol, embedded in paraffin, sectioned at 4-6 microns thickness and stained with Heamtoxylin and Eosin according to Carleton (1979).

\section{RESULTS AND DISCUSSION}

Nutrition evaluations:

\section{A-Biological changes:}

a- Boody weight gain, feed intake and feed efficiency ratio:

Feed intake (FI) values showed significant increases $(P \leq 0.05)$ for positive control group (C+) as compared to normal rats group $(23.72 \pm 0.23 \&$ $23.37 \pm 0.29 \mathrm{~g} /$ day, respectively). The higher values were recorded in pumpkin seeds group $(23.86 \pm 0.20 \mathrm{~g} /$ day $)$ when compared to normal rats group, as shown in Table (1).

In relation to body weight gain (BWG $\%)$, it could be observed that the mean value of the negative control group was 
non- significantly lower than the positive control group $(1.44 \pm 0.24 \& 1.75 \pm 0.45 \%$, respectively).Sunflower \& Flaxseeds revealed a higher value for increasing BWG\% level of obesitic rats when compared to negative control group $(2.02 \pm 0.49 \%)$ as shown in Table (1).

Calculation of feed efficiency ratio (FER) results of feed efficiency ratio (FER) which illustrated non-significant decreases between negative control group and positive control group ( $0.09 \pm$ $0.01 \& 0.11 \pm 0.02 \mathrm{~g}$, respectively).The best result found in pumpkin \& flax seeds group which closed to normal rats values, as shown in table (1).

The obtained results are in agreement with Bean and Leeson, (2003) found that feed intake was less $(P \leq 0.05)$ for hens fed flaxseed as compared to those consuming the control diet. In accordance to the present study, Salari et al., (2009) showed that weight gain, feed intake and feed conversion ratio (FCR) were improved $(p \leq 0.05)$ when broilers were fed various levels of full fat sunflower seeds (FFSS) in the starter and finisher diets. Also,present results (table 1) agree with those of Cassani et al., (2015) who indicated that flaxseed diet group experienced weight loss and systolic blood pressure reduction. A decrease in inflammatory markers (CRP and TNF- $\alpha$ ) was observed after flaxseed intake. Moreover, results agree with those of Abd El-Ghany et al., (2018) who showed that a significant decrease in weight gain; feed efficiency ratio in the pumpkin extract rat group .

\section{b- Relative organs weight:}

Relative liver weight value showed non-significant increases in normal rats group as compared to control $(\mathrm{C}+)$ group, it was $3.50 \pm 0.39$ and $3.25 \pm 0.44 \mathrm{~g}$, respectively. Mixed seeds revealed the lower value for decreasing liver of obesitic rats as compared to negative control group (2.64 $\pm 0.16 \mathrm{~g})$, as shown in Table (2) .

Table (1): Effect of different plant seeds diets on feed intake, body weight gain (BWG \%), and feed efficiency ratio (FER), of obese and treated rat groups ( $n=6$ rats)

\begin{tabular}{|l|c|c|c|}
\hline Groups & FI g/day & BWG\% & FER g \\
\hline Negative control & $23.37 \pm 0.29^{\mathrm{c}}$ & $1.44 \pm 0.24^{\mathrm{bc}}$ & $0.09 \pm 0.01^{\mathrm{bc}}$ \\
\hline Positive control & $23.72 \pm 0.23^{\mathrm{a}}$ & $1.75 \pm 0.45^{\mathrm{ab}}$ & $0.11 \pm 0.02^{\mathrm{ab}}$ \\
\hline Flaxseed & $23.68 \pm 0.20^{\mathrm{ab}}$ & $1.24 \pm 0.26^{\mathrm{c}}$ & $0.08 \pm 0.01^{\mathrm{c}}$ \\
\hline Sunflower seeds & $23.78 \pm 0.15^{\mathrm{a}}$ & $1.62 \pm 0.29^{\mathrm{abc}}$ & $0.10 \pm 0.01^{\mathrm{bc}}$ \\
\hline Pumpkin seeds & $23.86 \pm 0.20^{\mathrm{a}}$ & $1.55 \pm 0.31^{\mathrm{abc}}$ & $0.10 \pm 0.01^{\mathrm{bc}}$ \\
\hline Pumpkin \& Sunflower seeds & $23.73 \pm 0.15^{\mathrm{a}}$ & $1.55 \pm 0.46^{\mathrm{abc}}$ & $0.10 \pm 0.02^{\mathrm{b}}$ \\
\hline Pumpkin \& Flax seeds & $23.46 \pm 0.17^{\mathrm{bc}}$ & $1.63 \pm 0.28^{\mathrm{abc}}$ & $0.11 \pm 0.01^{\mathrm{a}}$ \\
\hline Sunflower \& Flax seeds & $23.47 \pm 0.17^{\mathrm{bc}}$ & $2.02 \pm 0.49^{\mathrm{a}}$ & $0.13 \pm 0.02^{\mathrm{b}}$ \\
\hline Mixed seeds & $23.47 \pm 0.18^{\mathrm{bc}}$ & $1.49 \pm 0.40^{\mathrm{bc}}$ & $0.10 \pm 0.02^{\mathrm{b}}$ \\
\hline
\end{tabular}

Values denote arithmetic means \pm standard deviation of the mean. Means with different letters (a, b, c, d, etc.) in the same column differ significantly at $p \leq 0.05$ using Duncan Range Multiple test, while those with similar letters are non-significantly different. 
Table (2): Effect of different plant seeds on relative organs weight $\%$ of obese and treated rat groups ( $n=6$ rats)

\begin{tabular}{|l|c|c|c|}
\hline Groups & Liver & Heart & Kidneys \\
\hline Negative control & $3.50 \pm 0.39^{\mathrm{a}}$ & $0.53 \pm 0.09^{\mathrm{b}}$ & $1.26 \pm 0.23^{\mathrm{a}}$ \\
\hline Positive control & $3.25 \pm 0.44^{\mathrm{ab}}$ & $0.54 \pm 0.25^{\mathrm{b}}$ & $1.14 \pm 0.19^{\mathrm{a}}$ \\
\hline Flaxseed & $2.98 \pm 0.26^{\mathrm{bc}}$ & $0.28 \pm 0.12^{\mathrm{c}}$ & $0.56 \pm 0.09^{\mathrm{d}}$ \\
\hline Sunflower seeds & $2.78 \pm 0.14^{\mathrm{cd}}$ & $0.51 \pm 0.14^{\mathrm{b}}$ & $0.80 \pm 0.16^{\mathrm{c}}$ \\
\hline Pumpkin seeds & $3.05 \pm 0.11^{\mathrm{bc}}$ & $0.61 \pm 0.16^{\mathrm{b}}$ & $0.51 \pm 0.05^{\mathrm{d}}$ \\
\hline Pumpkin \& Sunflower seeds & $2.84 \pm 0.14^{\mathrm{cd}}$ & $0.49 \pm 0.08^{\mathrm{b}}$ & $0.49 \pm 0.03^{\mathrm{d}}$ \\
\hline Pumpkin \& Flax seeds & $2.89 \pm 0.17^{\mathrm{cd}}$ & $0.89 \pm 0.05^{\mathrm{a}}$ & $0.48 \pm 0.02^{\mathrm{d}}$ \\
\hline Sunflower \& Flax seeds & $2.83 \pm 0.21^{\mathrm{cd}}$ & $0.48 \pm 0.05^{\mathrm{b}}$ & $0.93 \pm 0.04^{\mathrm{bc}}$ \\
\hline Mixed seeds & $2.64 \pm 0.16^{\mathrm{d}}$ & $0.55 \pm 0.05^{\mathrm{b}}$ & $0.96 \pm 0.09^{\mathrm{b}}$ \\
\hline
\end{tabular}

Values denote arithmetic means \pm standard deviation of the mean. Means with different letters (a, b, c, d, etc.) in the same column differ significantly at $p \leq 0.05$ using Duncan Range Multiple test, while those with similar letters are non-significantly different.

Relative heart weight value showed non-significant increases in control $(\mathrm{C}+)$ group as compared to normal rats group, it was $0.54 \pm 0.25 \& 0.53 \pm 0.09 \mathrm{~g}$, respectively. The best result found in Sunflower seeds and Mixed seeds groups, they were near to normal rats values. Pumpkin \& Flax seeds group revealed the higher value for increasing heart of obesitic rats as compared to negative control group ( $0.89 \pm 0.05 \mathrm{~g})$, as shown in Table (2).

Relative Kidneys weight value showed non-significant decreases in control (C+) group as compared to normal rats group, it was $1.14 \quad \pm 0.19 \quad \& 1.26 \quad \pm 0.23$ respectively). The best result found in Mixed seeds which closed to negative control group values, as shown in Table (2) .

\section{B- Biochemical analysis:}

a- Serum lipid profile:

Data of Table (3) revealed that the mean values of cholesterol showed a significant increases in positive control group as compared to negative control group $(258.5 \pm 11.43$ and $123.83 \pm 13.07 \mathrm{c}$ $\mathrm{mg} / \mathrm{dl}$, respectively). The best result found in mixed seeds groups which was near to healthy rats values. The higher values were recorded in group of Sunflower seeds, it was $157.17 \pm 27.32$ $\mathrm{mg} / \mathrm{dl}$ when compared to normal rats group as shown in Table (3).

In the same table, the mean values of triglycerides showed a significant increases in positive control group as compared to negative control group, it was $170.17 \pm 9.91$ and $95.17 \pm 3.32 \mathrm{mg} / \mathrm{dl}$, respectively. The higher values were recorded in groups of Sunflower seeds and Pumpkin seeds, it was $123.17 \pm 37.86$ and $116.17 \pm 19.32 \mathrm{mg} / \mathrm{dl}$, respectively when compared to normal rats group as shown in Table (3). Lowest triglycerides recorded for flaxseeds, pumpkin \&flaxseeds and sunflower \&flaxseeds groups.

The obtained results are in agreement with Khalesia et al., (2011) who found that 30 days consumption of flaxseed may significantly reduce total cholesterol. 
Data of Table (3) are also in accordance to the present study of Abuelgassim and Showayman, (2012) who indicated that atherogenic rats supplemented with pumpkin seeds showed a significant decrease $(p \leq 0.001)$ in their serum concentrations of total cholesterol. Also, result are in agreement with those of Hussein et al., (2014) they showed that, treatment with flaxseed oil to high cholesterol diet induced hypercholesterolemia rats, lowered serum total cholesterol, triacylglycerols. Moreover, data agree with those of Atefeh et al., (2018) who revealed that significant reductions in total cholesterol, low-density lipoprotein cholesterol [5.6\% in flaxseed oil (FO) and $10.8 \%$ in sunflower seed oil (SO)], and triglyceride levels were seen within each group after treatment with (FO) and (SO) $(P<.05)$.

Data of Table (4) revealed that the levels of HDL which were significantly higher in (C-) rats declined in case of (C+) group $(44.5 \pm 4.6 \& 34 \pm 1.67 \mathrm{mg} / \mathrm{dl}$, respectively). Most of treated groups indicated non-significant increases as compared to positive control group except Sunflower seeds, Pumpkin seeds and Pumpkin \& Flax seeds which showed significant increases ( $P \leq 0.05)$. The best result found in Pumpkin seeds groups which closed to normal rats values, as shown in Table (4).

The mean value of LDL in (negative control) group was extremely significantly lower than the $(\mathrm{C}+)$ group $(60.3 \pm 15.20 \quad \& \quad 190.47 \pm 10.37 \mathrm{mg} / \mathrm{dl}$, respectively). Mixed seeds revealed the best result for decreasing LDL of obesitic rats when compared to positive control group, as shown in Table (4).

The mean value of VLDL in (negative control) group was extremely significant lower than the $(C+)$ group $(19.03 \pm 0.66$ \&34.03 $\pm 1.98 \mathrm{mg} / \mathrm{dl}$, respectively). All treated groups showed a significant decrease $(P \leq 0.05)$ as compared to positive control group rats. The best result found in Flaxseed seeds, Pumpkin \& Flax seeds and Sunflower \& Flax seeds groups which indicat nearly to normal rats values, as shown in Table (4)

Table (3): Effect of different plant seeds on lipid profile of obese and treated rat groups $(n=6$ rats)

\begin{tabular}{|c|c|c|}
\hline Groups & Total Cholesterol (mg/dl) & Triglyceride (mg/dl) \\
\hline Negative control & $123.83 \pm 13.07^{c}$ & $95.17 \pm 3.32^{d}$ \\
\hline Positive control & $258.5 \pm 11.43^{a}$ & $170.17 \pm 9.91^{a}$ \\
\hline Flaxseed & $141.83 \pm 41.04^{b c}$ & $92.17 \pm 18.41^{d}$ \\
\hline Sunflower seeds & $157.17 \pm 27.32^{b}$ & $123.17 \pm 37.86^{b}$ \\
\hline Pumpkin seeds & $152.83 \pm 14.25^{b c}$ & $116.17 \pm 19.32^{b c}$ \\
\hline Pumpkin \& Sunflower seeds & $141.33 \pm 28.35^{b c}$ & $109.17 \pm 7.31^{\mathrm{bcd}}$ \\
\hline Pumpkin \& Flax seeds & $146.17 \pm 10.87^{b c}$ & $93.17 \pm 3.97^{d}$ \\
\hline Sunflower \& Flax seeds & $147.83 \pm 11.96^{b c}$ & $93.5 \pm 6.09^{d}$ \\
\hline Mixed seeds & $136.83 \pm 30.42^{b c}$ & $100.5 \pm 7.82^{\mathrm{cd}}$ \\
\hline
\end{tabular}

Values denote arithmetic means \pm standard deviation of the mean. Means with different letters (a, b, c, d, etc.) in the same column differ significantly at $p \leq 0.05$ using Duncan Range Multiple test, while those with similar letters are non-significantly different. 
Table (4): Effect of different plant seeds on lipoproteins profile obese and treated rat groups ( $n=6$ rats)

\begin{tabular}{|l|c|c|c|}
\hline Groups & $\begin{array}{c}\text { HDL } \\
(\mathrm{mg} / \mathrm{dl})\end{array}$ & $\begin{array}{c}\text { LDL } \\
(\mathrm{mg} / \mathrm{dl})\end{array}$ & $\begin{array}{c}\text { VLDL } \\
(\mathrm{mg} / \mathrm{dl})\end{array}$ \\
\hline Negative control & $44.5 \pm 4.6^{\mathrm{a}}$ & $60.3 \pm 15.20^{\mathrm{c}}$ & $19.03 \pm 0.66^{\mathrm{c}}$ \\
\hline Positive control & $34 \pm 1.67^{\mathrm{c}}$ & $190.47 \pm 10.37^{\mathrm{a}}$ & $34.03 \pm 1.98^{\mathrm{a}}$ \\
\hline Flaxseed & $36.17 \pm 3.55^{\mathrm{c}}$ & $87.23 \pm 38.41^{\mathrm{bc}}$ & $18.43 \pm 3.68^{\mathrm{b}}$ \\
\hline Sunflower seeds & $42.5 \pm 4.76^{\mathrm{ab}}$ & $90.03 \pm 24.15^{\mathrm{bc}}$ & $24.63 \pm 7.57^{\mathrm{bc}}$ \\
\hline Pumpkin seeds & $44.17 \pm 5.49^{\mathrm{a}}$ & $85.43 \pm 13.83^{\mathrm{bc}}$ & $23.23 \pm 3.86^{\mathrm{bc}}$ \\
\hline Pumpkin \& Sunflower seeds & $34.83 \pm 3.76^{\mathrm{c}}$ & $84.67 \pm 28.72^{\mathrm{bc}}$ & $21.83 \pm 1.46^{\mathrm{b}}$ \\
\hline Pumpkin \& Flax seeds & $42.5 \pm 4.23^{\mathrm{ab}}$ & $85.03 \pm 10.03^{\mathrm{bc}}$ & $18.63 \pm 0.79^{\mathrm{bc}}$ \\
\hline Sunflower \& Flax seeds & $34.17 \pm 3.31^{\mathrm{c}}$ & $94.97 \pm 12.27^{\mathrm{b}}$ & $18.70 \pm 1.22^{\mathrm{b}}$ \\
\hline Mixed seeds & $38.83 \pm 3.97^{\mathrm{bc}}$ & $77.9 \pm 31.67^{\mathrm{bc}}$ & $20.10 \pm 1.56^{\mathrm{bc}}$ \\
\hline
\end{tabular}

Values denote arithmetic means \pm standard deviation of the mean. Means with different letters (a, b, $c$, d, etc.) in the same column differ significantly at $p \leq 0.05$ using Duncan Range Multiple test, while those with similar letters are non-significantly different.

The obtained results are in agreement with Hussein et al., (2014) who showed that treatment with flaxseed oil accompanied high cholesterol diet induced hypercholesterolemia rats, lowered serum LDL-C, VLDL-C, phospholipid, endothelin-1 and homocysteine concentration in addition to increasing HDL-C. These results suggest that, flaxseed oil may be effective in controlling cholesterolemic status \& improving dyslipidemia and has the potential in reducing cardiovascular complications due to hypercholesterolemia. Also, data agree with those of Jalbani et al., (2016), they reported that in two months therapy by Flaxseeds decreased LDL-cholesterol $6.2 \%$ and increased HDL-cholesterol $7.7 \%$.). Moreover, agree with those of Mohamed et al., (2011) who revealed that the rats in the treated groups apricot kernel oil (AO) and pumpkin kernel oil (PO) showed significantly lower levels of total cholesterol (TC), total triglycerides (TG), low density lipoprotein-cholesterol (LDL-C). It could be concluded that AO and PO under study are useful for the treatment of hypercholesterolemia.
Data in Table (5) revealed that the level of LDL/ HDL which was significant lower in (C-) rats increased in case of (C+) group $(1.38 \pm 0.44 \& 5.62 \pm 0.50 \mathrm{mg} / \mathrm{dl}$, respectively). The best result found in Pumpkin seeds group which closed to negative control group values. Sunflower \& Flax seeds revealed the higher value for increasing LDL/ HDL of obesitic rats when compared to negative control group $(2.81 \pm 0.47 \mathrm{mg} / \mathrm{dl})$, as shown in Table (5).

The mean value of Cardiac Risk Ratio (CRR) in (C-) group was extremely significant lower than the $(\mathrm{C}+)$ group $(2.82 \pm 0.48 \quad \& \quad 7.62 \pm 0.59 \quad \mathrm{mg} / \mathrm{dl}$, respectively). All supplemented diets showed a significant decreases ( $P \leq 0.05)$ as compared to positive control group rats. The higher values were recorded in group of Sunflower \& Flax seeds (4.36 \pm $0.52 \mathrm{mg} / \mathrm{dl}$ ) when compared to normal rats group. Pumpkin \& Flax seeds revealed the best result for decreasing CRR of obesitic rats when compared to negative control group, as shown in Table (5). 
Study the nutritional and therapeutic effect of flaxseed, sunflower ................

Table (5): Effect of different plant seeds on LDL-C/HDL-C ratio, Cardiac Risk Ratio (CRR), Atherogenic Coefficient (AC) and Atherogenic Index of Plasma (AIP) of obese and treated rat groups $(n=6$ rats).

\begin{tabular}{|l|c|c|c|c|}
\hline Groups & $\begin{array}{c}\text { LDL /HDL } \\
(\mathrm{mg} / \mathrm{dl})\end{array}$ & $\begin{array}{c}\text { CRR } \\
(\mathrm{mg} / \mathrm{dl})\end{array}$ & $\begin{array}{c}\text { AC } \\
(\mathrm{mg} / \mathrm{dl})\end{array}$ & $\begin{array}{c}\text { AIP } \\
(\mathrm{mg} / \mathrm{dl})\end{array}$ \\
\hline Negative control & $1.38 \pm 0.44^{\mathrm{c}}$ & $2.82 \pm 0.48^{\mathrm{d}}$ & $1.82 \pm 0.48^{\mathrm{c}}$ & $0.33 \pm 0.049^{\mathrm{d}}$ \\
\hline Positive control & $5.62 \pm 0.50^{\mathrm{a}}$ & $7.62 \pm 0.59^{\mathrm{a}}$ & $6.62 \pm 0.59^{\mathrm{a}}$ & $0.69 \pm 0.043^{\mathrm{a}}$ \\
\hline Flaxseed & $2.41 \pm 1.01^{\mathrm{bc}}$ & $3.92 \pm 1.03^{\mathrm{b}}$ & $2.92 \pm 1.03^{\mathrm{b}}$ & $0.40 \pm 0.07^{\mathrm{cd}}$ \\
\hline Sunflower seeds & $2.16 \pm 0.66^{\mathrm{bc}}$ & $3.73 \pm 0.74^{\mathrm{bc}}$ & $2.73 \pm 0.74^{\mathrm{bc}}$ & $0.45 \pm 0.11^{\mathrm{bc}}$ \\
\hline Pumpkin seeds & $1.96 \pm 0.43^{\mathrm{b}}$ & $3.51 \pm 0.56^{\mathrm{bc}}$ & $2.51 \pm 0.56^{\mathrm{bc}}$ & $0.42 \pm 0.12^{\mathrm{bcd}}$ \\
\hline Pumpkin \& Sunflower seeds & $2.48 \pm 0.92^{\mathrm{bc}}$ & $4.11 \pm 0.97^{\mathrm{b}}$ & $3.11 \pm 0.97^{\mathrm{b}}$ & $0.49 \pm 0.04^{\mathrm{b}}$ \\
\hline Pumpkin \& Flax seeds & $2.02 \pm 0.30^{\mathrm{b}}$ & $3.46 \pm 0.33^{\mathrm{bc}}$ & $2.46 \pm 0.33^{\mathrm{bc}}$ & $0.34 \pm 0.04^{\mathrm{d}}$ \\
\hline Sunflower \& Flax seeds & $2.81 \pm 0.47^{\mathrm{b}}$ & $4.36 \pm 0.52^{\mathrm{b}}$ & $3.36 \pm 0.52^{\mathrm{b}}$ & $0.44 \pm 0.05^{\mathrm{bc}}$ \\
\hline Mixed seeds & $2.04 \pm 0.88^{\mathrm{bc}}$ & $3.56 \pm 0.90^{\mathrm{bc}}$ & $2.56 \pm 0.90^{\mathrm{bc}}$ & $0.41 \pm 0.04^{\mathrm{bcd}}$ \\
\hline
\end{tabular}

Values denote arithmetic means \pm standard deviation of the mean. Means with different letters $(a, b, c, d$, etc.) in the same column differ significantly at $p \leq 0.05$ using Duncan Range Multiple test, while those with similar letters are non-significantly different.

The mean value of Atherogenic Coefficient (AC) in (C-) group was extremely significant lower than the $(\mathrm{C}+)$ group $(1.82 \pm 0.48 \& 6.62 \pm 0.5 \mathrm{mg} / \mathrm{dll}$, respectively). All treated groups showed significant decrease $(P \leq 0.05)$ as compared to positive control group rats. The best result found in Pumpkin \& Flax seeds group which closed to normal rats values, as shown in Table (5).

In the same table, the obtained results showed that there was significant increase atherogenic index of plasma (AIP) in positive control group as compared to normal rats. In rats feed on all treatment diets, there was significant decrease $(P \leq 0.05)$ in Atherogenic Index of Plasma (AIP) as compared to (C+). The best result found in Pumpkin \& Flax seeds groups which was closed to normal rats values as shown in Table (5).

b- Liver function:

1- Liver enzymes( GOT\& GPT )

The mean value of GPT (ALT) showed a significant increase in positive control group as compared to negative control group, it was $86.83 \pm 17.84$ and $23.5 \pm 2.34$ U/L, respectively. The best result found in Sunflower \& Flax seeds group which closed to negative control group values. Sunflower seeds revealed the higher value for increasing GPT of obesitic rats when compared to negative control group ( $50 \pm 10.43 \mathrm{U} / \mathrm{L})$, as shown in Table (6).

In relation to GOT(AST), it could be observed that the mean value of positive control group was significantly higher than negative control group $(69.67 \pm 18.12$ \& 23.67 $\pm 8.48 \mathrm{U} / \mathrm{L}$, respectively). The best result found in Pumpkin \& Sunflower seeds and Sunflower \& Flax seeds groups which closed to normal rats values. Sunflower seeds revealed the higher value for increasing GOT of obesitic rats when compared to negative control group (40 $\pm 8.41 \mathrm{U} / \mathrm{L})$, as shown in Table (6). 
Table (6): Effect of different plant seeds on liver enzymes of obese and treated rat groups $(n=6$ rats)

\begin{tabular}{|l|c|c|}
\hline Groups & GPT (U/L) & GOT (U/L) \\
\hline Negative control & $26.83 \pm 5.74^{\text {de }}$ & $23.67 \pm 8.48^{\mathrm{c}}$ \\
\hline Positive control & $86.83 \pm 17.84^{\mathrm{a}}$ & $69.67 \pm 18.12^{\mathrm{a}}$ \\
\hline Flaxseed & $31.33 \pm 3.14^{\text {cde }}$ & $20 \pm 3.16^{\mathrm{c}}$ \\
\hline Sunflower seeds & $50 \pm 10.43^{\mathrm{b}}$ & $40 \pm 8.41^{\mathrm{b}}$ \\
\hline Pumpkin seeds & $39.50 \pm 6.06^{\mathrm{c}}$ & $30.50 \pm 6.95^{\mathrm{bc}}$ \\
\hline Pumpkin \& Sunflower seeds & $30.83 \pm 4.79^{\text {cde }}$ & $22 \pm 3.03^{\mathrm{c}}$ \\
\hline Pumpkin \& Flax seeds & $35.33 \pm 2.94^{\text {cde }}$ & $35.67 \pm 7.39^{\mathrm{b}}$ \\
\hline Sunflower \& Flax seeds & $25.50 \pm 3.33^{\mathrm{e}}$ & $24.33 \pm 4.84^{\mathrm{c}}$ \\
\hline Mixed seeds & $36.16 \pm 4.31^{\mathrm{cd}}$ & $35.5 \pm 2.74^{\mathrm{b}}$ \\
\hline
\end{tabular}

Values denote arithmetic means \pm standard deviation of the mean. Means with different letters (a, b, c, d, etc.) in the same column differ significantly at $p \leq 0.05$ using Duncan Range Multiple test, while those with similar letters are non-significantly different.

The obtained results are in agreement with Cheenam and Leena (2016) found that the patients that were being fed on the sunflower seeds showed a positive and a faster decrease in their liver function test (LFT) levels (both SGOT and SGPT). The SGOT and SGPT levels were found to be decreased from $89.7 \mathrm{mg} / \mathrm{dl}$ to $38.4 \mathrm{mg} / \mathrm{dl}$ in the Case group and 37.6 $\mathrm{mg} / \mathrm{dl}$ to $40.5 \mathrm{mg} / \mathrm{dl}$ in Control group. Moreover, Al-Okbi et al., (2014) reported that pumpkin seed oil reversed all histopathological changes that occur in liver tissue which became comparable to normal in some rats.

\section{2-Protein fractions: (Total Protein,} Albumin, Globulin and Albumin/Globulin (A/G) ratio):

The mean value of total protein showed a significant decrease in positive control group as compared to negative control group, it was $6.02 \pm 0.81$ and $6.97 \pm 0.46 \mathrm{mg} / \mathrm{dl}$, respectively. All treated groups indicated non- significant increases $(P \leq 0.05)$ as compared to positive control group. The best result found in Pumpkin seeds and Mixed seeds groups which closed to negative control group values. Sunflower \& Flax seeds revealed the lower value for decreasing total protein of obesitic rats when compared to negative control group (5.88 $\pm 0.23 \mathrm{mg} / \mathrm{dl})$, as shown in Table (7).

In the same table, results presented the mean values of albumin and showed a significant decrease in positive control group as compared to negative control group, it was $3.83 \pm 0.32$ and $4.38 \pm 0.37$ $\mathrm{mg} / \mathrm{dl}$, respectively. All supplemented diets caused a significant increases $(P \leq 0.05)$ as compared to positive control group. The best result found in Pumpkin \&Sunflower seeds group which closed to negative control group values. Sunflower \& Flax seeds revealed the lowest value of decreasing albumin level of obesitic rats when compared to negative control group $(3.73 \pm 0.19 \mathrm{mg} / \mathrm{dl})$, as shown in Table (7). 
Study the nutritional and therapeutic effect of flaxseed, sunflower ................

Table (7): Effect of different plant seeds on serum proteins of obese and treated rat groups ( $n=6$ rats)

\begin{tabular}{|l|c|c|c|c|}
\hline Groups & $\begin{array}{c}\text { Total protein } \\
(\mathrm{mg} / \mathrm{dl})\end{array}$ & $\begin{array}{c}\text { Albumin } \\
(\mathrm{mg} / \mathrm{dl})\end{array}$ & $\begin{array}{c}\text { Globulin } \\
(\mathrm{mg} / \mathrm{dl})\end{array}$ & $\begin{array}{c}\text { A/G ratio } \\
(\mathrm{mg} / \mathrm{dl})\end{array}$ \\
\hline Negative control & $6.97 \pm 0.46^{\mathrm{a}}$ & $4.38 \pm 0.37^{\mathrm{a}}$ & $2.58 \pm 0.54^{\mathrm{a}}$ & $1.77 \pm 0.44^{\mathrm{a}}$ \\
\hline Positive control & $6.02 \pm 0.81^{\mathrm{b}}$ & $3.83 \pm 0.32^{\mathrm{b}}$ & $2.18 \pm 0.64^{\mathrm{ab}}$ & $1.86 \pm 0.43^{\mathrm{a}}$ \\
\hline Flaxseed & $6.03 \pm 0.26^{\mathrm{b}}$ & $4.05 \pm 0.41^{\mathrm{ab}}$ & $1.98 \pm 0.25^{\mathrm{b}}$ & $2.09 \pm 0.49^{\mathrm{a}}$ \\
\hline Sunflower seeds & $6.17 \pm 0.59^{\mathrm{b}}$ & $3.97 \pm 0.39^{\mathrm{ab}}$ & $2.2 \pm 0.35^{\mathrm{ab}}$ & $1.83 \pm 0.28^{\mathrm{a}}$ \\
\hline Pumpkin seeds & $6.45 \pm 0.73^{\mathrm{ab}}$ & $3.93 \pm 0.46^{\mathrm{ab}}$ & $2.52 \pm 0.49^{\mathrm{ab}}$ & $1.62 \pm 0.41^{\mathrm{a}}$ \\
\hline Pumpkin \& Sunflower seeds & $6.28 \pm 0.22^{\mathrm{ab}}$ & $4.2 \pm 0.36^{\mathrm{ab}}$ & $2.08 \pm 0.46^{\mathrm{ab}}$ & $2.18 \pm 0.91^{\mathrm{a}}$ \\
\hline Pumpkin \& Flax seeds & $6.23 \pm 0.53^{\mathrm{b}}$ & $4.18 \pm 0.45^{\mathrm{ab}}$ & $2.05 \pm 0.43^{\mathrm{ab}}$ & $2.13 \pm 0.57^{\mathrm{a}}$ \\
\hline Sunflower \& Flax seeds & $5.88 \pm 0.23^{\mathrm{b}}$ & $3.73 \pm 0.19^{\mathrm{b}}$ & $2.15 \pm 0.19^{\mathrm{ab}}$ & $1.75 \pm 0.19^{\mathrm{a}}$ \\
\hline Mixed seeds & $6.35 \pm 0.78^{\mathrm{ab}}$ & $3.9 \pm 0.47^{\mathrm{ab}}$ & $2.43 \pm 0.33^{\mathrm{ab}}$ & $1.61 \pm 0.10^{\mathrm{a}}$ \\
\hline
\end{tabular}

Values denote arithmetic means \pm standard deviation of the mean. Means with different letters (a, b, $c$, d, etc.) in the same column differ significantly at $p \leq 0.05$ using Duncan Range Multiple test, while those with similar letters are non-significantly different.

In relation to globulin, it could be observed that the mean value of positive control group was non-significantly lower than negative control group $(2.18 \pm 0.64 \&$ $2.58 \pm 0.54 \mathrm{mg} / \mathrm{dl}$, respectively). All treated groups indicated non-significant differences as compared to positive control group. The best result found in Pumpkin seeds group which closed to normal rats values. Flaxseed seeds revealed the lower value for decreasing globulin level of obesitic rats when compared to negative control group (1.98 $\pm 0.25 \mathrm{mg} / \mathrm{dl})$, as shown in Table (7).

Also in the same table, the obtained results showed that there was nonsignificant increase in albumin/globulin $(A / G)$ ratio in $(C+)$ as compared to normal rats $(1.86 \pm 0.43 \& 1.77 \pm 0.44 \mathrm{mg} / \mathrm{dl}$, respectively). In rats fed on all treatment diets, there was non-significant differences in $A / G$ as compared to positive control group. The best result found in Sunflower \& Flax seeds group which closed to negative control group values, as shown in Table (7).

\section{C- Kidney functions :}

1- Uric acid, urea and creatinine

The mean value of urea values showed non- significant increase in control (C+) group as compared to normal rats group $(37.5 \pm 5.54 \& 32 \pm 5.22$ $\mathrm{mg} / \mathrm{dL}$, respectively). All treated groups indicated non-significant differences as compared to positive control group except Pumpkin \& Sunflower seeds and Pumpkin \& Flax seeds which showed significant differences. The best result found in Sunflower \& Flax seeds and Pumpkin seeds groups which nearly to normal rats values as shown in Table (8).

In relation to creatinine, it could be observed that the mean value of positive control group was significantly higher than negative control group $(1.29 \pm 0.44$ \& $0.65 \pm 0.104 \mathrm{mg} / \mathrm{dL}$, respectively). All treated groups indicated significant decreases $(P \leq 0.05)$ as compared to 
positive control group. The best result found in Pumpkin \& Sunflower seeds and Sunflower seeds group which nearly to normal rats values. Mixed seeds group revealed the higher values in increasing creatinine of obesitic rats when compared to negative control group $(0.92$ $\pm 0.16 \& 0.65 \pm 0.104 \mathrm{mg} / \mathrm{dL}$, respectively) as shown in Table (8).

Calculation of uric acid results illustrated non-significant increase in control (C+) group as compared to normal rats group $(1.83 \pm 0.39$ and $1.73 \pm 0.22 \mathrm{mg} / \mathrm{dL}$, respectively). All treated groups recorded non-significant increase $(P \leq 0.05)$ values except Pumpkin \& Sunflower seeds and Mixed seeds groups which showed significant increase as compared to positive control group. The best result found in Flaxseed seeds and Sunflower seeds groups which closed to normal rats values as shown in Table (8).

\section{d- Antioxidant enzymes and lipid peroxidation}

The mean value of GPx showed a significant decrease in positive control group as compared to negative control group, it was $2.37 \pm 1.59$ and $3.94 \pm 0.21$ $\mu \mathrm{u} / \mathrm{mL}$, respectively. The best result found in Pumpkin \& Flax seeds and Sunflower \& Flax seeds group which closed to negative control group values. Sunflower seeds revealed the lower value of GPx of obesitic rats when compared to negative control group $(2.71 \pm 0.07 \mu \mathrm{u} / \mathrm{mL})$, as shown in Table (9).

In relation to MDA, it could be observed that the mean value of positive control group was significantly higher than negative control group $(7.62 \pm 0.59 \&$ $2.82 \pm 0.48 \mathrm{nmol} / \mathrm{mL}$, respectively). The best result found in Pumpkin \& Flax seeds group which closed to normal rats values. Sunflower \& Flax seeds revealed the higher value for MDA of obesitic rats when compared to negative control group $(4.36 \pm 0.52 \mathrm{nmol} / \mathrm{mL})$, as shown in Table (9).

Table (8): Effect of different plant seeds on kidney functions of obese and treated rat groups $(n=6$ rats $)$

\begin{tabular}{|l|c|c|c|}
\hline Groups & $\begin{array}{c}\text { Urea } \\
(\mathrm{mg} / \mathrm{dl})\end{array}$ & $\begin{array}{c}\text { Creatinine } \\
(\mathrm{mg} / \mathrm{dl})\end{array}$ & $\begin{array}{c}\text { Uric acid } \\
(\mathrm{mg} / \mathrm{dl})\end{array}$ \\
\hline Negative control & $32 \pm 5.22^{\mathrm{bc}}$ & $0.65 \pm 0.104^{\mathrm{b}}$ & $1.73 \pm 0.22^{\mathrm{b}}$ \\
\hline Positive control & $37.5 \pm 5.54^{\mathrm{ab}}$ & $1.29 \pm 0.44^{\mathrm{a}}$ & $1.83 \pm 0.39^{\mathrm{b}}$ \\
\hline Flaxseed & $41.33 \pm 5.20^{\mathrm{a}}$ & $0.83 \pm 0.09^{\mathrm{b}}$ & $1.87 \pm 0.55^{\mathrm{b}}$ \\
\hline Sunflower seeds & $40.67 \pm 6.05^{\mathrm{a}}$ & $0.72 \pm 0.22^{\mathrm{b}}$ & $1.8 \pm 0.29^{\mathrm{b}}$ \\
\hline Pumpkin seeds & $31 \pm 3.09^{\mathrm{bc}}$ & $0.75 \pm 0.16^{\mathrm{b}}$ & $2.03 \pm 0.26^{\mathrm{ab}}$ \\
\hline Pumpkin \& Sunflower seeds & $26.5 \pm 4.59^{\mathrm{c}}$ & $0.71 \pm 0.15^{\mathrm{b}}$ & $2.33 \pm 0.36^{\mathrm{a}}$ \\
\hline Pumpkin \& Flax seeds & $28.67 \pm 7.03^{\mathrm{c}}$ & $0.77 \pm 0.16^{\mathrm{b}}$ & $1.9 \pm 0.18^{\mathrm{b}}$ \\
\hline Sunflower \& Flax seeds & $30.83 \pm 8.06^{\mathrm{bc}}$ & $0.85 \pm 0.09^{\mathrm{b}}$ & $2.13 \pm 0.27^{\mathrm{ab}}$ \\
\hline Mixed seeds & $37.33 \pm 3.87^{\mathrm{ab}}$ & $0.92 \pm 0.16^{\mathrm{b}}$ & $2.35 \pm 0.16^{\mathrm{a}}$ \\
\hline
\end{tabular}

Values denote arithmetic means \pm standard deviation of the mean. Means with different letters (a, b, c, d, etc.) in the same column differ significantly at $p \leq 0.05$ using Duncan Range Multiple test, while those with similar letters are non-significantly different. 
Study the nutritional and therapeutic effect of flaxseed, sunflower ................

Table (9): Effect of different plant seeds on antioxidant enzyme levels (SOD, CAT \& GPX) and lipid peroxidation as MDA of obese treated rat groups $(n=6$ rats)

\begin{tabular}{|l|c|c|c|c|}
\hline Groups & $\begin{array}{c}\text { GPX } \\
(\mu \mathrm{u} / \mathrm{mL})\end{array}$ & $\begin{array}{c}\text { MDA } \\
(\mathrm{nmol} / \mathrm{mL})\end{array}$ & $\begin{array}{c}\text { SOD } \\
(\mathrm{U} / \mathrm{mL})\end{array}$ & $\begin{array}{c}\text { Catalase } \\
(\mathrm{U} / \mathrm{L})\end{array}$ \\
\hline Negative control & $3.94 \pm 0.21^{\mathrm{a}}$ & $2.82 \pm 0.48^{\mathrm{b}}$ & $988 \pm 123.09^{\mathrm{ab}}$ & $85.33 \pm 6.56^{\mathrm{b}}$ \\
\hline Positive control & $2.37 \pm 1.59^{\mathrm{c}}$ & $7.62 \pm 0.59^{\mathrm{a}}$ & $460.83 \pm 44.62^{\mathrm{d}}$ & $50 \pm 21.61^{\mathrm{d}}$ \\
\hline Flaxseed & $3.63 \pm 1.36^{\mathrm{ab}}$ & $3.92 \pm 1.03^{\mathrm{ab}}$ & $920.17 \pm 52.58^{\mathrm{ab}}$ & $76.33 \pm 7.20^{\mathrm{bc}}$ \\
\hline Sunflower seeds & $2.71 \pm 0.07^{\mathrm{bc}}$ & $3.74 \pm 0.74^{\mathrm{b}}$ & $816.83 \pm 95.25^{\mathrm{c}}$ & $64.50 \pm 5.13^{\mathrm{c}}$ \\
\hline Pumpkin seeds & $3.48 \pm 0.32^{\mathrm{ab}}$ & $3.51 \pm 0.56^{\mathrm{b}}$ & $898.17 \pm 52.66^{\mathrm{bc}}$ & $73.67 \pm 12.01^{\mathrm{bc}}$ \\
\hline Pumpkin \& Sunflower seeds & $3.41 \pm 0.63^{\mathrm{ab}}$ & $4.11 \pm 0.97^{\mathrm{b}}$ & $911 \pm 13.04^{\mathrm{b}}$ & $75.33 \pm 9.42^{\mathrm{bc}}$ \\
\hline Pumpkin \& Flax seeds & $3.93 \pm .82^{\mathrm{a}}$ & $3.46 \pm 0.33^{\mathrm{b}}$ & $968.17 \pm 73.08^{\mathrm{ab}}$ & $78.33 \pm 13.84^{\mathrm{bc}}$ \\
\hline Sunflower \& Flax seeds & $3.93 \pm 0.55^{\mathrm{a}}$ & $4.36 \pm 0.52^{\mathrm{b}}$ & $1005.83 \pm 71.75^{\mathrm{a}}$ & $119 \pm 12.68^{\mathrm{a}}$ \\
\hline Mixed seeds & $2.93 \pm 0.11 \mathrm{a}^{\mathrm{bc}}$ & $3.56 \pm 0.90^{\mathrm{b}}$ & $935.5 \pm 46.07^{\mathrm{ab}}$ & $82 \pm 9.72^{\mathrm{b}}$ \\
\hline
\end{tabular}

Values denote arithmetic means \pm standard deviation of the mean. Means with different letters (a, b, c, d, etc.) in the same column differ significantly at $p \leq 0.05$ using Duncan Range Multiple test, while those with similar letters are non-significantly different.

In the same table show the mean values of SOD showed a significant decrease $(\mathrm{P} \leq 0.05)$ in positive control group as compared to negative control group, it was $(460.83 \pm 44.62$ and $988 \pm 123.09 \mathrm{U} / \mathrm{mL}$, respectively). All treated group showed a significant increases $(P \leq 0.05)$ when comparing with positive control group. Pumpkin \& Flax seeds group revealed the best result for increasing SOD of obesitic rats when compared to negative control group (1005.83 $\pm 71.75 \mathrm{U} / \mathrm{mL}$, respectively), as shown in Table (9).

Calculation of Catalase results illustrated a significant decrease in control (C+) group as compared to normal rats group $(50 \pm 21.61$ and 85.33 $\pm 6.56 \mathrm{U} / \mathrm{L}$, respectively). All treated groups recorded significant increased $(P \leq 0.05)$ values when comparing with positive control group. The best result found in Mixed seeds group which closed to normal rats values. Sunflower \& Flax seeds revealed the higher value for increasing Catalase of obesitic rats when compared to negative control group (119 $\pm 12.68 \mathrm{U} / \mathrm{L})$, as shown in Table (9).

The obtained results are in agreement with Rajesha et al., (2006), they found that treated with $10.0 \%$ flaxseed has shown the restoration of $95.02 \%$, $182.31 \%$, and $136.0 \%$ of catalase, SOD, and peroxidase. In the case of the group treated with toxin without flaxseed, the level of superoxide dismutase and the catalse value decreased $91.4 \%$ and $55.33 \%$, respectively, in comparison with the control group. These results clearly indicate the beneficial effect of flaxseed components as an antioxidant. In accordance to the present study Shivanna et al., (2013) reported that the flaxseed group had significantly 
decreased monoamine oxidase $A$ and $B$ activity and increased superoxide dismutase activity. Lipid peroxidation was completely inhibited. Also, data agree with those of Hussien et al., (2016), they reported that treatment with flaxseed oil in hypercholesterolemic rats ameliorate antioxidant enzymatic decreases in liver tissue such as (CAT, SOD and GPx). Also, it agree with those of Abd El-Ghany et al., (2018) found that the pumpkin extract and oil rats groups showed a significant decrease in blood GPX \& SOD. Moreover, data agree with those of Makni et al., (2010) who indicated that diet supplemented with flax and pumpkin seed mixture in the DMS group ameliorated antioxidant enzymes activities and level of reduced glutathione (GSH) in diabetic rats and significantly decreased MDA levels.

C. Histopathological changes of hearts.

Photos ( 1 to 9$)$ indicated that due to obesity inducation control $(+)$ rats revealed certain histopathological changes in particular portal infiltration with inflammatory cells (Photo 2).No histopathological changes occurred when rats fed with different kinds of seeds (Photos 3,4,5,6,7,8,9).

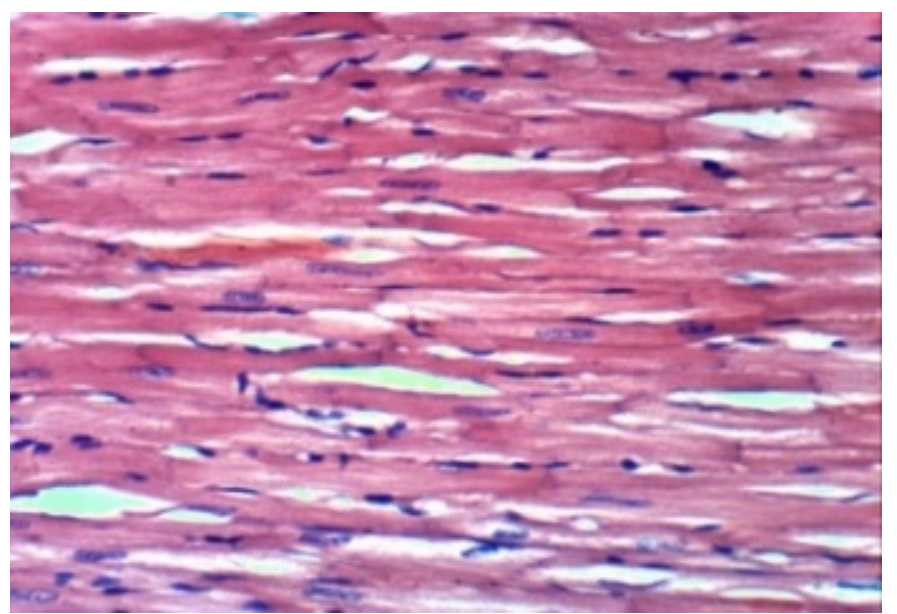

Photo (1): Heart of rat from (C-) showing the normal histological structure of cardiac myocytes (H \& E X 400).

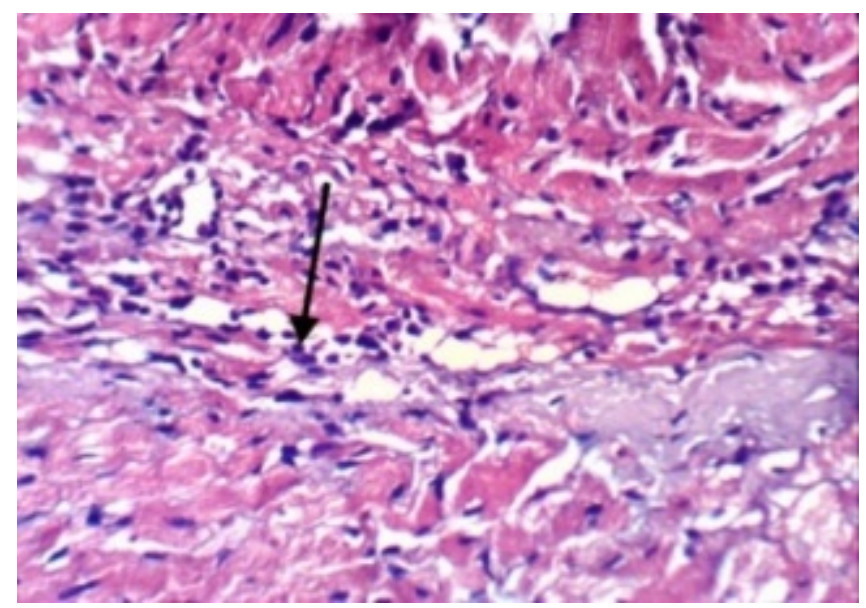

Photo (2): Heart of rat from (C+) showing focal necrosis of cardiac myocytes associated with inflammatory cells infiltration ( $H$ \& E X 400). 


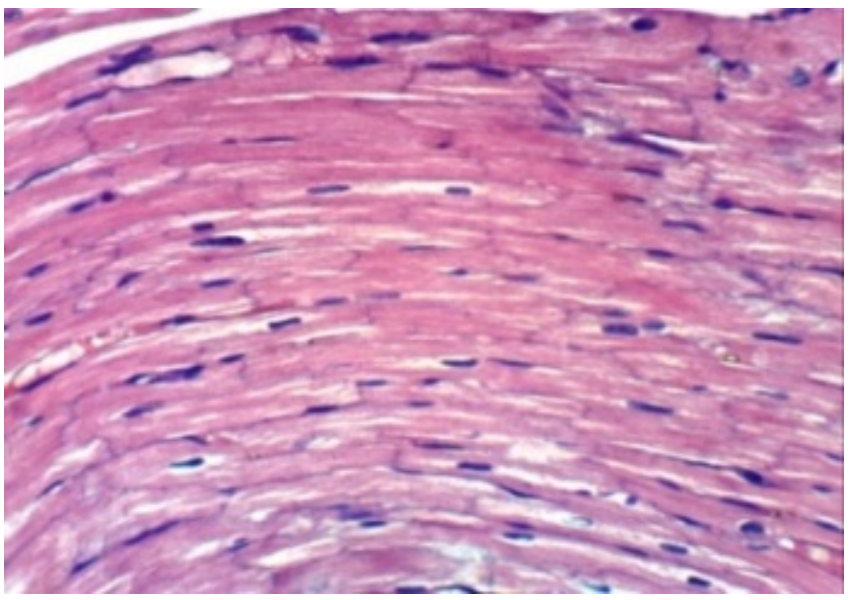

Photo (3): Heart of rat from (Pumpkin seed diet group) showing no showing nohistopathological changes (H \& E X 400).

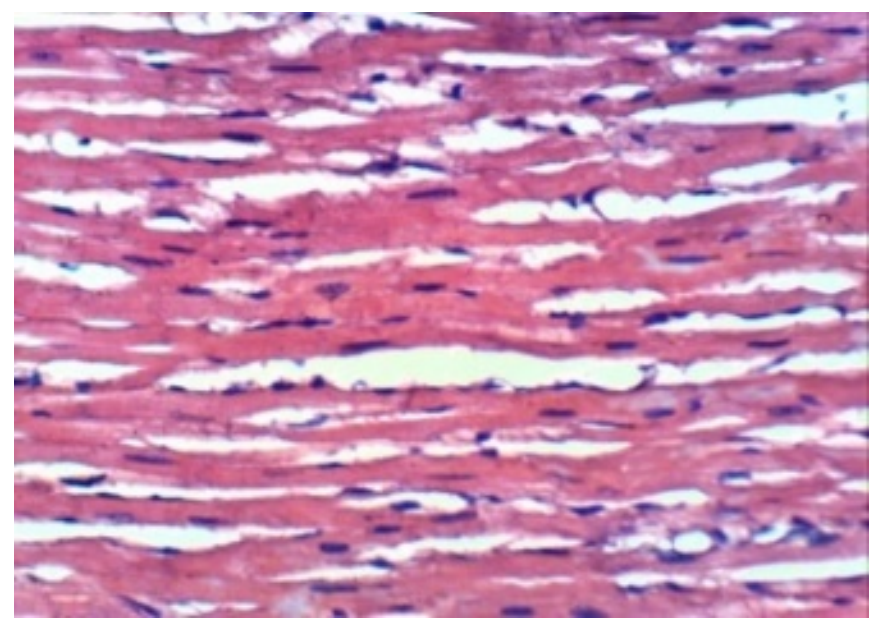

Photo (4): Heart of rat from (flaxseed diet group no histopathological changes (H \& E X 400).

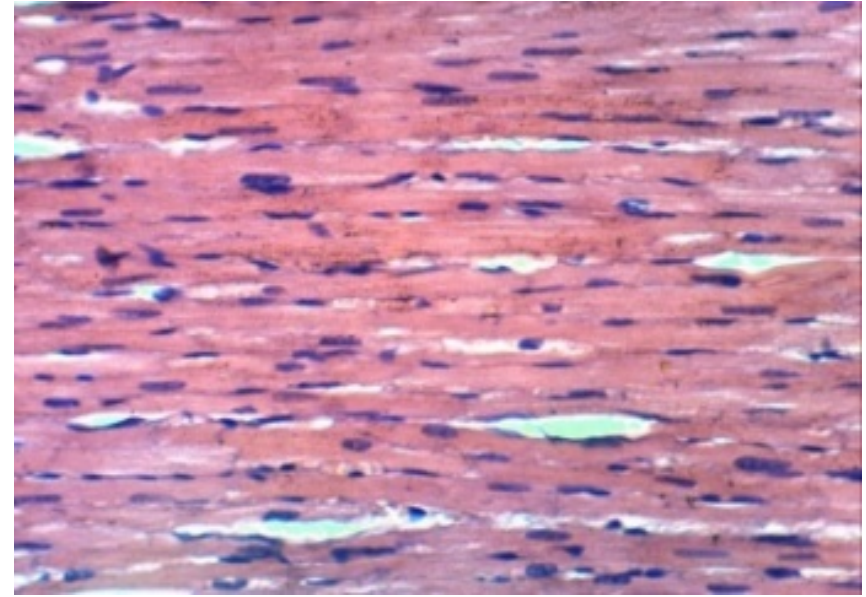

Photo (5): Heart of rat from (sunflower seed diet group) showing no seeds) histopathological changes (H \& E X 400). 


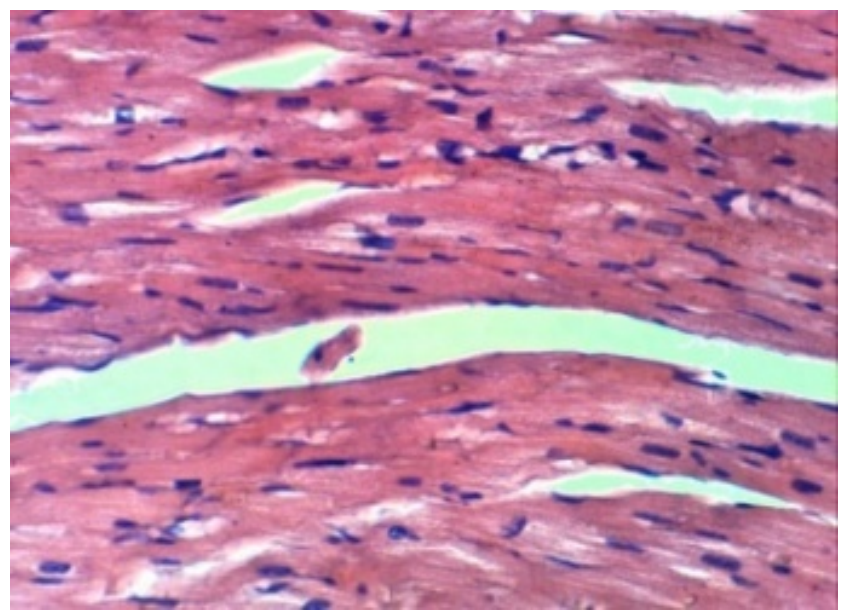

Photo (6): Heart of rat from (pumpkin and sunflower showing no histopathological changes ( $H$ \& E X 400).

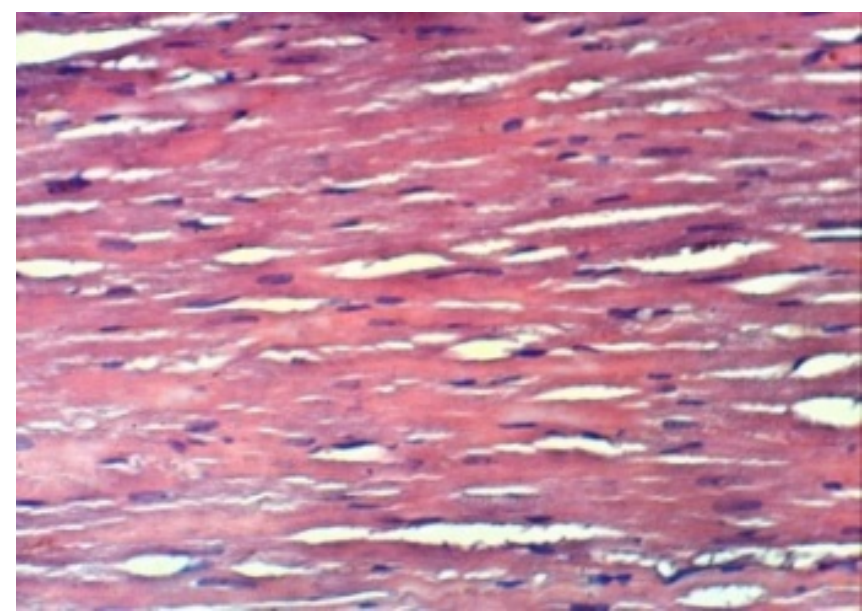

Photo (7): Heart of rat from (pumpkin and flaxseed) diet group showing no histopathological changes (H \& E X 400).

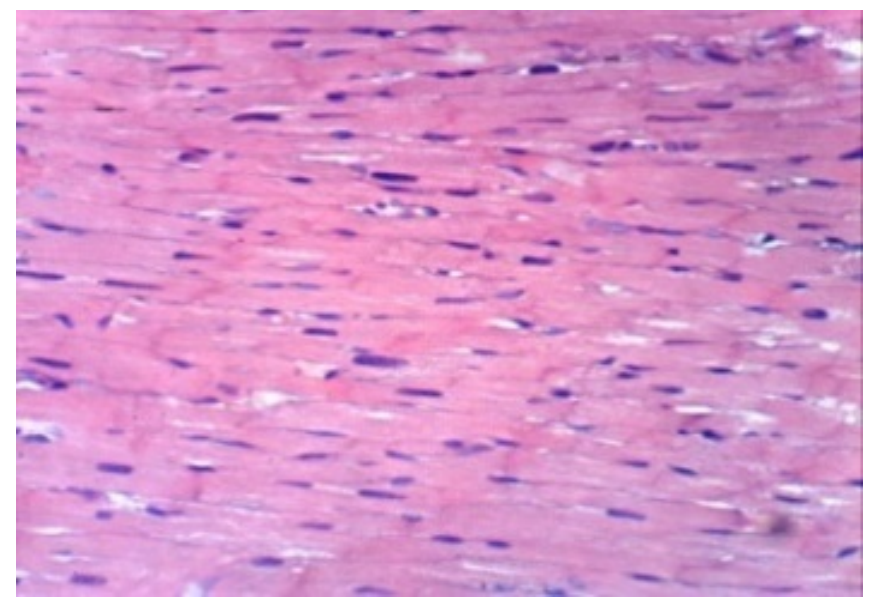

Photo (8): Heart of rat from (sunflower and flaxseed) diet group showing no histopathological changes (H \& E X 400). 


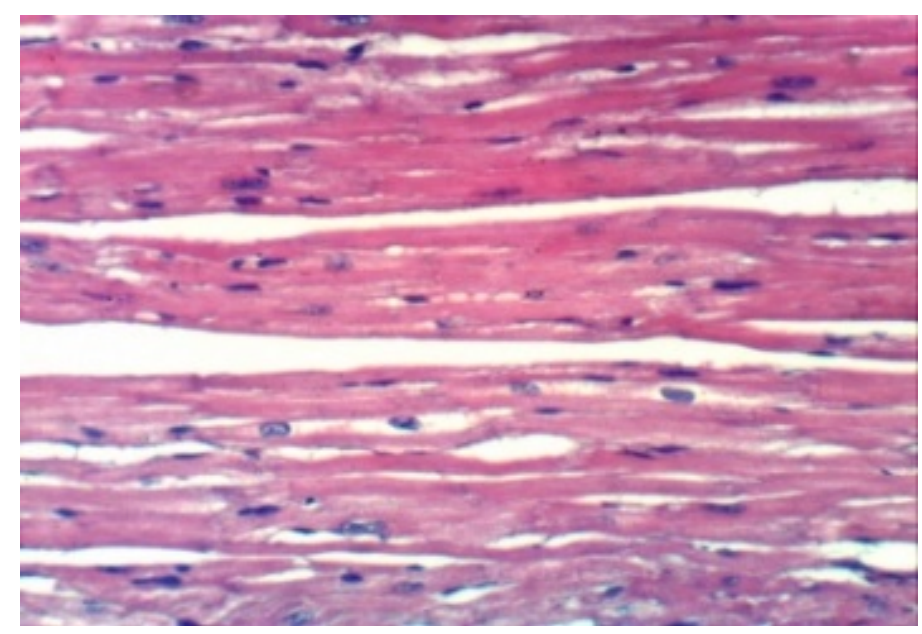

Photo (9): Heart of rat from (sunflower, pumpkin and flaxseed diet group) showing no histopathological changes (H \& E X 400).

\section{REFERENCES}

Abd El-Ghany, M. A., Dalia A. Hafez, Soha M. and S. El-Safty (2018). Biological study on the effect of pumpkin seeds and zinc on reproductive potential of male rats. Available at: https://www.researchgate.net/publicati on/322068627_Biological_study_on_th e_effect_of_pumpkin_seeds_and_zinc on_reproductive_potential_of_male_r ats_The_5_th_Arab_and_2_nd_Interna tional_Annual_Scientific_Conference on_Recent_Trends_of_Developing_In stitu.

Abuelgassim, O. and I.A. Showayman (2012). The effect of pumpkin (Cucurbita pepo, L) seeds and arginine supplementation on serum lipid concentrations in atherogenic rats. African Journal Tradition Complement Alternative Medicines, 9(1):131-137.

Aebi, H. (1984). Methods Enzymol 105, 121-126.

Allain, C. C., L. S. Poon and C. S. Chan (1974). Enzymatic determination of serum total cholesterol. Clinical Chemistry, 20 (4): 470-475.
Al-Okbi, S.Y., Thanaa E., D.M. Hamed and Reham S.H. (2014). Rice bran oil and pumpkin seed oil alleviate oxidative injury and fatty liver in rats fed high fructose diet. Polish Journal of Food and Nutrition Sciences,64(2):127-133.

Armitage, P. and G. Berry (1987). Statistical Methods in Medical Research. Blackwell, Oxford, UK, 93213.

Atefeh, A., Farzad, N., B. Siavash, F. Shiva and M. Hassan (2018). Comparison of the effects of flaxseed oil and sunflower seed oil consumption on serum glucose, lipid profile, blood pressure, and lipid peroxidation in patients with metabolic syndrome. Journal of Clinical Lipidology,12(1):70-77.

Bean, L.D. and S. Leeson (2003). Longterm effects of feeding flaxseed on performance and egg fatty acid composition of brown and white hens. Poultry Science, 82(3): 388-394.

Beutler, E., O. Duron and M.B. Kelly (1963). J Lab Clin. Med. 61-882.

Bhardwaj, S., J. Bhattacharjee, M. K. Bhatnagar and S. Tyagi (2013). Atherogenic index of plasma, castelli 
risk index and atherogenic coefficientnew parameters in assessing cardiovascular risk. IJPBS, 3 (3): 359364.

Bleich, S., D. Cutler, C. Murray and A. Adams (2008). Why is the developed world obese?. Annual Review of Public Health (Research Support), 29: 273-95.

Campbell, J.A. (1963). Methodology of Protein Evaluation. PAG Nutr. Document R. 101 Led. 37 June Meeting. New York.

Carleton, H. (1979). Histological Technique $4^{\text {th }}$ Ed., London, Oxford University Press, New York, Toronto.

Cassani, R.S., G.P. Fassini, J.H. Silvah, C. Maria and J.S. Marchini (2015). Impact of weight loss diet associated with flaxseed on inflammatory markers in men with cardiovascular risk factors: a clinical study. Nutrition Journal, 14(5): 75-91.

Catherine, W.J., L.T. Daniel and E. H. Pamela (2003). Essential Laboratory Mathematics: Concepts and Applications for the Chemical and Clinical Laboratory Technician. Ed: 2nd (140): 268.

Cheenam, B. and P. Leena (2016). Effects of sunflower seeds on LFT levels of patients with fatty liver. Journal of Innovations in Pharmaceutical and Biological Sciences (JIPBS), 23492759.

Colquitt, J.L., K. Pickett, E. Loveman and G.K. Frampton (2014). Surgery for weight loss in adults. The Cochrane Database of Systematic Reviews (Meta-analysis, Review), 8 (8): 20-26.

Drupt, F. (1974). Colorimetric method for determination of albumin. Pharm. Biol., 9: 777-779.
Drury, R. A. and E. A. Wallington (1980). Carletons Histological technique $5^{\text {th }}$ Ed .Oxford Univ.

Faulkner, N. R. and J. W. King (1976). Fundamental of Clinical Chemistry. $2^{\text {nd }}$ Ed. Tietz editor. Saunders, Philadelphia. 994-998.

Fossati, P., L. Prencipe and G. Berti (1980). Enzymatic colorimetric method for determination of uric acid in serum. Clin. Chem. 26, 227-231

Friedwald, W. T., R. I. Leve and D. S. Fredrickson (1972). Estimation of the concentration of low-density lipoprotein separated by three different methods. Clinical Chemistry, 18: 499-502.

Garg, S., K. Surendra, K.G. Suresh, P. Ishan, G. Akhil and A. Chakranarayan (2017). Effect of Alsi/Flaxseed (Linum Usitatissimum) on different physiological and biochemical metabolic derangements in metabolic syndrome in northwest zone of Rajasthan. International Journal of Research Studies in Medical and Health Sciences, 2 (3): 21-26.

Haslam, D.W. and W.P. James (2005). Obesity. Scientific research, 366 (9492):1197-

1209.Available at: doi:10.1016/S01406736(05)67483-1.

Hegested, A. (1941). Salt mixture. The Journal of Biological Chemistry, 138:459.

https://www.medicalnewstoday.com/articl es/303864.php

https://www.medicalnewstoday.com/articl es/303864.php

Hussein, S.A., Y.A. El-Senosi, M.R. Ragab and M.F. Mohammed (2014). Beneficial effect of flaxseed oil on lipid metabolism in high cholesterol diet fed rats. Benha Veterinary Medical Journal ( BVMJ), 27(2): 290-301. 
Hussien, S.A., A.F. Yakout, M.R. Hassanien and M.M. Hammad (2016). Evaluation of the protective role of flaxseed oil on inflammatory mediators, antioxidant defense system and oxidative stress of liver tissue in hypercholesterolemic rats. International Journal of Pharma Sciences, 6(3):1480-1489.

Imaz, I., C. Martinez-Cervell, E. E. GarciaAlvarez, J. M. Sendra-Gutierrez and E.J. Gonzalez (2008). Safety and effectiveness of the intragastric balloon for obesity. A meta-analysis. Obesity Surgery, 18 (7): 841-846.

Jalbani, G.A., H. Shaheena, S. Murad, N. Khalid, Q. Abdul, M. Hafiz and F. Ajaz (2016). Flaxseeds and ajwain for primary hyperlipidemia. Journal of Drug Delivery \& Therapeutics, 6(2):3739.

Khalesia, S., J. Rosita and A. Ismailab (2011). Effect of raw and heated flaxseed (Linum usitatissimum, L.) on blood lipid profiles in rats. International Journal of Applied Science and Technology,1(4): 269-275.

Kushner, R. (2009). Treatment of the obese patient (contemporary endocrinology). Totowa NJ: Humana Press, 158(97): 40-45.

Lopes-Virella, M. F., S. Stone, S. Ellis and J. A. Collwell (1977). Cholesterol determination in high-density lipoprotein separated by three different methods. Clinical Chemistry, 23 (5): 882.

Luppino, F.S., L.M. de, P.F. Bouvy, T. Stijnen, P. Cuijpers, B.W. Penninx and F.G. Zitman (2010). Overweight, obesity, and depression: A systematic review and meta-analysis of longitudinal studies. Archives of General Psychiatry, 67 (3): 220-229.

Makni, M., M. Sefi, M.F. Hamadi, G. N. El Mouldi, K. Gargouri and Z. Najiba
(2010). Flax and Pumpkin seeds mixture ameliorates diabetic nephropathy in rats. Food and Chemical Toxicology,48(8-9) :24072412.

Marcene, B. (2018). 11 Amazing Health Benefits of Sunflower Seeds. Natural Food Series, Available at: https://www.naturalfoodseries.com/11benefits-sunflower-seedsl.

Megan, W. R. (2018). What are the health benefits of pumpkin seeds? Medical news today. Available at:

Mohamed, F. R., R. Zayed, M. Abozid and M.M. Asker (2011). Apricot and pumpkin oils reduce plasma cholesterol and triacylglycerol concentrations in rats fed a high-fat diet. grasas y aceites, 62 (4): 443-452.

NRC (1995). National Research Council. Nutrient Requirements of Laboratory Animals, Received Edition, PP(29-30), National Academy Press. Washington, D.C, U.S.A.

Ohkawa, H., W. Ohishi and K. Yagi (1979): Anal. Biochem, 95-351.

Patton, C. J. and S. R. Crouch (1977). Enzymatic colorimetric method for determination of urea in serum. Anal. Chem., 49: 464-469.

Rajesha, J., N. Kotamballi, M. Chidambara, M.K. Karun, M.G. Basavaraj and Ravishankar, A.(2006): Antioxidant potentials of flaxseed by in vivo model. Journal of Agricultural and Food chemistry, 54 (11) :37943799.

Rashwan, N. M. (1994): Ph.D Thesis, Nutrition and Food Science Dept. Faculty of Home Economics. Hellwan University.

Reitman, S. and S. Frankel (1957). A colorimetric method for the determination of serum glutamic oxaloacetic and glutamic pyruvic 
transaminases. Am. J. Clin. Path., 28:56.

Salari, S., H.N. Moghaddam, J. Arshami and A. Golian (2009). Nutritional evaluation of full-fat sunflower seed for broiler chickens. Asian Aust Journal of Animal Science, 22(4):557 564.

Schermer, S. (1967). The Blood Morphology of Laboratory Animals. $3^{\text {rd }}$ Ed., F. A. Davis Company, Philadelphia,5-24.

Shivanna, N., S. Mahadevappa, S. Dongzagin and K. Farhath (2013). Antidepressive effect of polyphenols and omega 3 fatty acid from pomegranate peel and flaxseed in mice exposed to chronic mild stress. Psychiatry and Clinical Neurosciences, 67(7): 501-508.

Sonnenwirth, A. and L. Jaret (1980). Grad Wholes Clinical Laboratory Methods and Diagnosis.Vol.18 ${ }^{\text {th }}$ Ed Mosby, London 258-259.

Trinder, P. and S. Ann (1969). Enzymatic colorimetric test with lipid clearing factor to determine triglycerides. Clin. Biochem., 6:24-27.

WHO (2016). Obesity and overweight. Fact Sheet $\mathrm{N}^{\circ} 311$ [online]. Available at:

<http:/lwww.who.int/mediacentre/facts heets/ fs31//en/ index.

Yanovski, S.Z. and J.A. Yanovski (2014). Long-term drug treatment for obesity: A systematic and clinical review. JAMA, 311 (1): 74-86.

Yazdi, F.T., S.M. Clee and D. Meyre (2015). Obesity genetics in mouse and human: Back and forth, and back again. Peer J., 3(8). Available at: https://peerj.com/articles/856/ 


$$
\begin{aligned}
& \text { دراسة التأثير الغذائي والعلاجي لبذور الكتان ودوار الثمس والقرع على مستوي } \\
& \text { دهون الام وزيادة الوزن لادى الفئران }
\end{aligned}
$$

محمد مصطفى السيد علي، فاطمة جابر راغب الهواري

قسم التغنية وعلوم الأطعمة - كلية الاقتصاد المنزلى - جامعة المنوفيلة راغب العاري

الملخص العربى

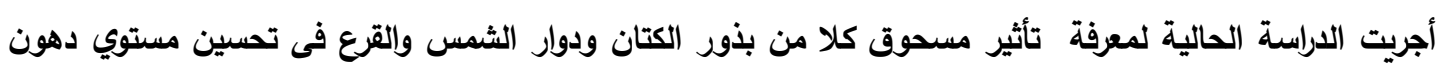

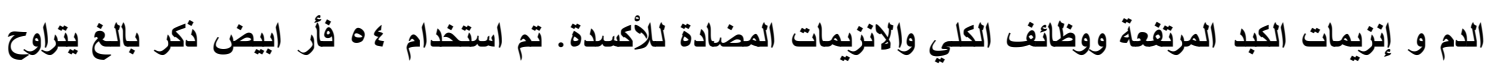

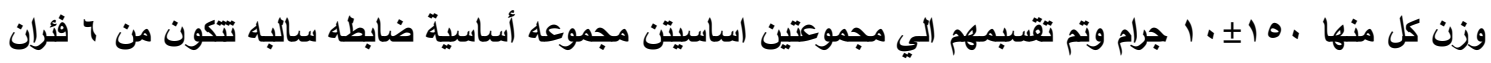

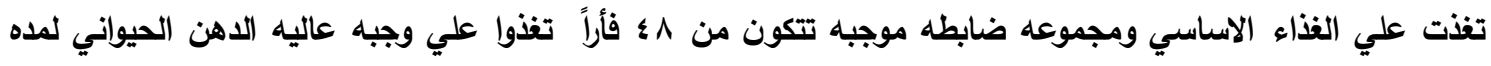

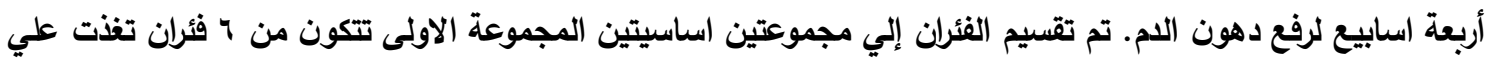

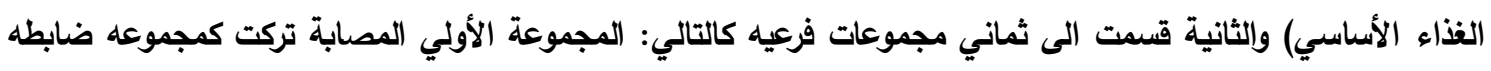

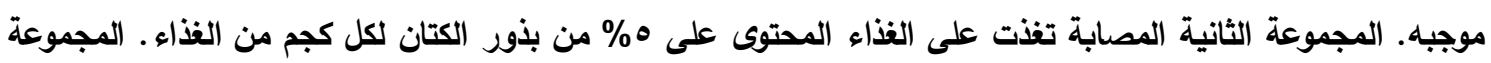

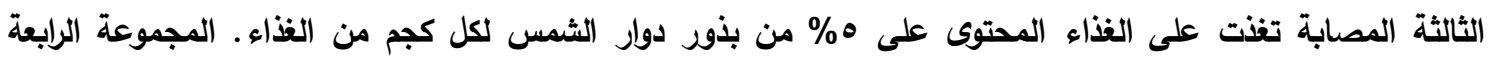

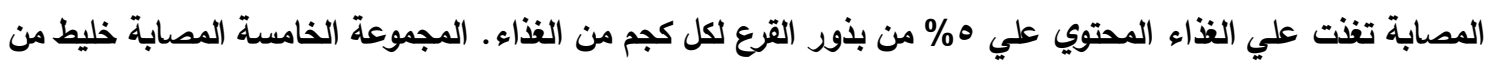

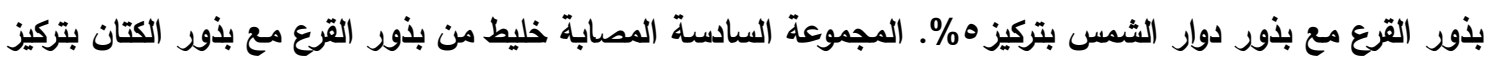

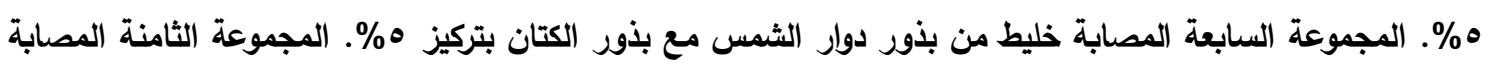

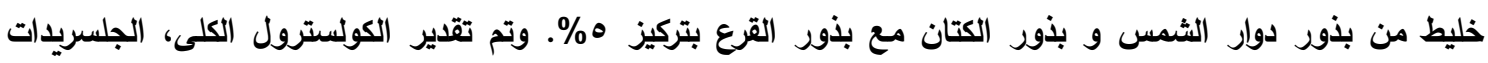

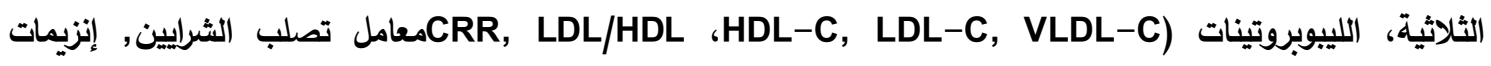

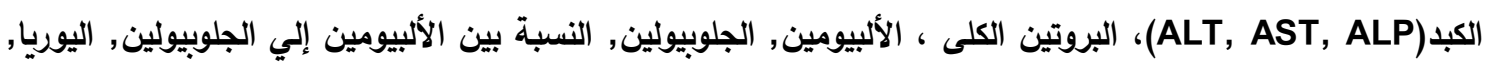

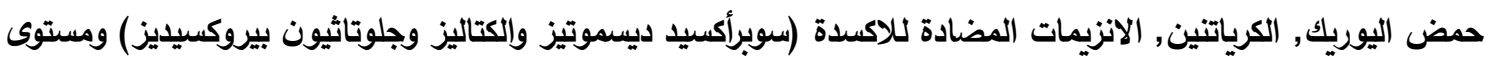

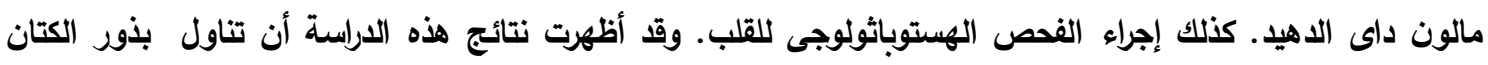

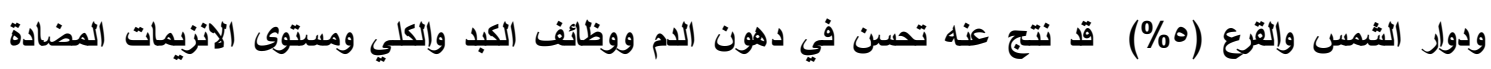

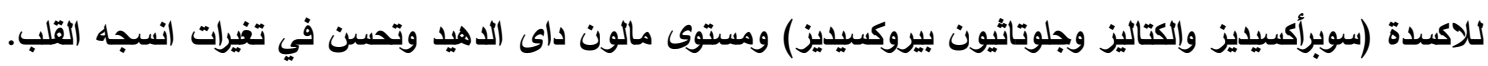

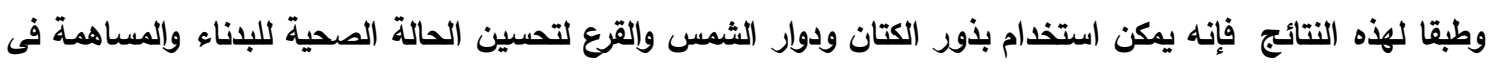

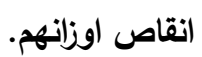
الكلمات المفتاحية: السمنة، دهون اللام، إنزيمات الكبد، الانزيمات المضادة للاكسدة (سوبرأكسيد ديسموتيز والكتاليز

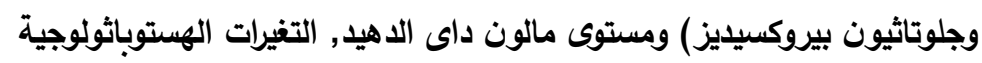

أسماء السادة المحكمين

كلية الأقتصاد المنزلى - جامعة المنوفية أ. أدم/ فاطمة الزهراء أمين الثريف الثين كلية الأقتصاد المنزلى - جامعة المنوفية المنئ - جامعة المنوفة

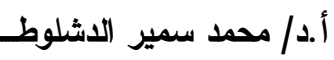


